\title{
THEORETICAL CHARACTERISTICS OF USING LEVERAGE INSTRUMENTS IN THE CONTEXT OF RURAL ENTREPRENEURSHIP
}

Tereza Korsaka $^{1}$, Mg.oec; Gunta Grinberga-Zalite², Dr.oec., prof.

${ }_{1,2}$ Latvia University of Life Sciences and Technologies

\begin{abstract}
Today, the matters pertaining to regional and urban development in the EU are increasingly integrated into EU development plans and strategies. The EU actively facilitates regional development by supporting the development of small and medium-sized enterprises in the regions to contribute to employment, education and social integration. The strategic goal of the National Development Plan of Latvia 2021-2027 is to promote also regional development in Latvia in order to ensure long-term balanced growth in the country. Promoting entrepreneurship in the regions is of great importance, as Latvia is still one of the countries in the European Union experiencing unbalanced regional development and having socio-economic disparities. Consequently, financial performance and financial stability play an important role in sustainable business development. Rural entrepreneurs whose business is seasonal often lack an awareness of the role of financial leverage degrees, which could lead to making wrong decisions. Performing an assessment of the degrees of financial leverage could be useful not only in a situation when experiencing a business expansion but also when a business decline occurs, which is specific to rural entrepreneurship.
\end{abstract}

A hypothesis of the present research is based on the authors' opinion that by meaningfully applying the degrees of financial leverage, it is possible to enhance the financial performance of enterprises, which is particularly important for rural entrepreneurship.

The aim of the research is to define the degrees of financial leverage - the degree of operating leverage (DOL), the degree of financial leverage (DFL) and the degree of combined leverage (DCL) - as measures of financial performance of enterprises and classify the principles of measure assessment in relation to whether the indicator percentage changes used in financial leverage calculations are positive or negative.

The research employed the following methods: induction - to make scientific assumptions and identify similarities based on individual elements - and deduction - to logically systematize and explain empirical data. Applying the empirical and logical construction methods, the authors analysed six different theoretically possible situations, gave six different examples, defined and classified the principles of leverage degree assessment as different (positive and negative) in relation to the indicator percentage changes used in financial leverage calculations.

Key words: financial performance, degree of operating leverage (DOL); degree of financial leverage (DFL); degree of combined leverage (DCL).

JEL code: M41

\section{Introduction}

To contribute to growth, development, employment and the standard of living in rural areas, the rural development policy of the European Union sets objectives, which include raising the competitiveness of agriculture and achieving sustainable and balanced territorial development in rural areas. One of the objectives of the Common Agricultural Policy of the European Union is to ensure a relatively high standard of living for the rural population; therefore, business development and promotion in rural areas play an important role in the sustainable development of rural areas.

The latest research substantiates the importance of business development in promoting regional development. The research study Regional Development through Entrepreneurial Exaptation: Epistemological Displacement, Affordances, and Collective Agency in Rural Regions stresses that "the creation of growth and development in rural regions presents a key challenge for both researchers and policy makers" (Gaddefors J., et al. 2020). In their research study, the authors focus on the importance of expanding business as a mechanism for creating regional development in rural areas.

${ }^{1}$ Tereza Korsaka e-mail: terezaterezakorsaka@gmail.com

2 Gunta Grinberga-Zalite e-mail: gunta.grinberga@llu.Iv 
Not only large enterprises but also small and medium ones and their expansion play an important role in regional development. The research studies focusing on profit efficiency and the factors affecting it, in small and medium enterprises in particular (Perez-Gmez, P., et al., 2018), reveal that enterprise size, export orientation, government support and productivity are positively related to the efficiency of small and medium enterprises.

The choice of the research topic was determined by the authors' opinion that financial leverage degrees are tools that could help rural entrepreneurs to monitor the financial performance of their enterprises, which is also an important factor in contributing to the financial success and value of the enterprise.

Scientists Modigliani and Miller, who each received a Nobel Prize in economics, concluded in their research that the value of a business should not depend on the structure of its capital. Financial risk arising from borrowed capital has to be managed by entrepreneurs in a way to ensure steady financial performance and effective business operation.

The authors of the paper have found that the matters pertaining to enterprise capital structure as well as the factors affecting decisions on optimal capital structure have been widely researched in fundamental literature (Amaro de M., J. (2001); Berk, J., et al. (2014); Brealey, R., et al. (2014); Brealey, R., et al. (2016); Corelly, A. (2016); Emery, D., R., at al. (1997); Hart, O. (1995); Jean Tirole (2006); Moyer, C., et al. (1998); Moles P., et al. (2011), Leibus (2019); Jones, C., P. (1992)).

The latest scientific research also focuses on financial leverage degrees as enterprise performance measures (Yang, R., et al. (2016), Stelk, S., et al. (2017), Sarkar, S. (2018), Li, Z., et al. (2016)).

The authors of the paper believe that that the problem of seasonality in rural entrepreneurship, which necessitates additional capital, irrespective of the capital structure of the enterprise (equity or borrowed capital), indicates the urgency to use financial leverage degrees to measure the financial performance of the enterprise.

A hypothesis of the present research is based on the authors' opinion that by meaningfully applying the degrees of financial leverage, it is possible to increase the financial performance of enterprises, which is particularly important for rural entrepreneurship.

The aim of the research is to define the degrees of financial leverage - the degree of operating leverage (DOL), the degree of financial leverage (DFL) and the degree of combined leverage (DCL) - as measures of financial performance of enterprises and classify the principles of measure assessment in relation to whether the indicator percentage changes used in financial leverage calculations are positive or negative.

The research employed the following methods: induction - to make scientific assumptions and identify similarities based on individual elements - and deduction - to logically systematize and explain empirical data. Applying the empirical and logical construction methods, the authors analysed six different theoretically possible situations, gave six different examples, defined and classified the principles of leverage degree assessment as different (positive and negative) in relation to the indicator percentage changes used in financial leverage calculations.

\section{Research results and discussion}

Financial leverage degrees are calculated by dividing a percentage change in one indicator by a percentage change in another, so the result of the calculation indicates which rate of change is higher (the calculation employed profit and loss account indicators and EBIT). In analysing financial leverage 
degrees, focus has to be placed on a percentage change in the numerator. Compared with a percentage change in the denominator, the percentage change in the numerator has to be larger or positive.

Formulas for calculating financial leverage degrees (1, 2 and 3) Jones, Charles, P. (1992) are given below.

A formula for calculating a degree of operating leverage (DOL):

percentage change in EBIT / percentage change in net turnover

A formula for calculating a degree of financial leverage (DFL):

percentage change in net profit / percentage change in EBIT

A formula for calculating a degree of combined leverage (DCL):

percentage change in net profit / percentage change in net turnover

The authors designed and classified the principles of and criteria for assessment of degrees of financial leverage - the degree of operating leverage (DOL), the degree of financial leverage (DFL) and the degree of combined leverage (DCL) (Table 1).

Table 1

\begin{abstract}
Principles of assessment of degrees of financial leverage, depending on different (positive and negative) indicator values to be used in the calculation (profit and loss account indicators used in the calculation are as follows: net turnover, net profit of the reporting period and percentage change in EBIT)
\end{abstract}

\begin{tabular}{|l|l|l|l|}
\hline \multicolumn{3}{|c|}{ Degrees of operating, financial and combined leverage } \\
\hline \multicolumn{1}{|c|}{ Positive leverage degrees } & \multicolumn{1}{|c|}{2} & \multicolumn{1}{c|}{ Negative leverage degrees } \\
\hline \multicolumn{1}{|c|}{1} & \multicolumn{1}{|c|}{3} & \multicolumn{1}{c|}{4} \\
\hline $\begin{array}{l}\text { Percentage changes in both } \\
\text { the numerator and the } \\
\text { denominator of an indicator } \\
\text { are positive }\end{array}$ & $\begin{array}{l}\text { Percentage changes in both } \\
\text { the numerator and the } \\
\text { denominator of an indicator } \\
\text { are negative }\end{array}$ & $\begin{array}{l}\text { Percentage change is } \\
\text { positive in the numerator } \\
\text { and negative in the } \\
\text { denominator }\end{array}$ & $\begin{array}{l}\text { Percentage change is } \\
\text { negative in the } \\
\text { numerator and positive } \\
\text { in the denominator }\end{array}$ \\
\hline $\begin{array}{l}\text { Positive }(+) \text { if a leverage } \\
\text { degree }>1\end{array}$ & $\begin{array}{l}\text { Negative }(-) \text { if a leverage } \\
\text { degree }>1\end{array}$ & Negative $(-)$ \\
\cline { 1 - 2 } $\begin{array}{l}\text { Negative }(-) \text { if a leverage } \\
\text { degree }<1\end{array}$ & $\begin{array}{l}\text { Positive }(+) \text { if a leverage } \\
\text { degree }<1\end{array}$ & Positive $(+)$ & \\
\hline
\end{tabular}

Source: authors' compilation, 2020

To explain the information available in Table 1 , six various situations and six various practical examples are given below.

Situation 1. In calculating a leverage effect, a positive leverage degree occurs if the percentage changes in both the numerator and the denominator of an indicator are positive or if a leverage degree is above 1.

If using positive numbers in calculating leverage degrees, i.e. only positive percentage changes (in both the numerator and the denominator, i.e. profit and loss account indicators and EBIT are positive), the leverage degrees should be viewed as follows: the higher the leverage degree, the better. In fact, a positive result, i.e. a leverage degree of above 1 (one), yielded by positive numbers used to calculate leverage degrees should be viewed positively, as it indicates a high financial performance of the enterprise.

Practical example 1. The information and calculation results regarding the example are presented in Tables 2 and 3. 
Changes in the financial performance of enterprise $X$ : practical example 1

\begin{tabular}{|c|c|c|c|c|}
\hline $\begin{array}{c}\text { Financial performance } \\
\text { indicator }\end{array}$ & $\begin{array}{l}2018 \\
\text { (EUR) }\end{array}$ & $\begin{array}{l}2019 \\
\text { (EUR) }\end{array}$ & $\begin{array}{c}\text { Absolute change } \\
(+;-)(\text { EUR) }\end{array}$ & $\begin{array}{c}\text { Relative change } \\
(2019 / 2018),(\%)\end{array}$ \\
\hline 1 & 2 & 3 & $4=3-2$ & $5=4 \times 100 / 2$ \\
\hline Net turnover & 10000 & 14000 & +4000 & $+40 \%$ \\
\hline $\begin{array}{l}\text { EBIT (profit before interest } \\
\text { and taxes) }\end{array}$ & 1900 & 3900 & +2000 & $+105.26 \%$ \\
\hline Net profit & 1400 & 3110 & +1710 & $+122.14 \%$ \\
\hline
\end{tabular}

Source: authors' calculations, 2020

\section{Degrees of operating, financial and combined leverage for enterprise $X$ :} practical example 1

\begin{tabular}{|l|l|}
\hline \multicolumn{1}{|c|}{ Leverage degrees } & \multicolumn{1}{c|}{ Calculation result } \\
\hline 1 & \multicolumn{1}{c|}{2} \\
\hline Degree of operating leverage & $105.26 \% / 40 \%=2.63$ \\
\hline Degree of financial leverage & $122.14 \% / 105.26 \%=1.16$ \\
\hline Degree of combined leverage & $122.14 \% / 40 \%=3.05$ \\
\hline
\end{tabular}

Source: authors' calculations, 2020

As shown in Table 3, positive percentage changes used in calculating leverage degrees yield a result of above 1 , and the higher the leverage degree is obtained, the higher the financial performance of the enterprise is. The example shows that at a lower increase in net turnover (40\%), the enterprise has a higher increase in EBIT (105.26 \%) and a much higher increase in net profit $(122.14 \%)$

Situation 2. In calculating a leverage effect, a positive leverage degree occurs if the percentage changes in both the numerator and the denominator of an indicator are positive or if a leverage degree is below 1.

Practical example 2. The information and calculation results regarding the example are presented in Tables 4 and 5.

Changes in the financial performance of enterprise $X$ : practical example 2

\begin{tabular}{|l|c|c|c|c|}
\hline $\begin{array}{c}\text { Financial performance } \\
\text { indicator }\end{array}$ & $\begin{array}{c}\mathbf{2 0 1 8} \\
\text { (EUR) }\end{array}$ & $\begin{array}{c}\mathbf{2 0 1 9} \\
\text { (EUR) }\end{array}$ & $\begin{array}{c}\text { Absolute change } \\
(+;-)(E U R)\end{array}$ & $\begin{array}{c}\text { Relative change } \\
(\mathbf{2 0 1 9 / 2 0 1 8}),(\%)\end{array}$ \\
\hline 1 & 2 & 3 & $4=3-2$ & $5=4 \times 100 / 2$ \\
\hline Net turnover & $\mathbf{1 0 0 0 0}$ & $\mathbf{1 4 0 0 0}$ & +4000 & $+\mathbf{4 0} \%$ \\
\hline $\begin{array}{l}\text { EBIT (profit before interest } \\
\text { and taxes) }\end{array}$ & $\mathbf{2 9 0 0}$ & $\mathbf{3 9 0 0}$ & +1000 & $+\mathbf{3 4 . 4 8 \%}$ \\
\hline Net profit & $\mathbf{2 ~ 1 1 0}$ & $\mathbf{2 ~ 4 0 0}$ & +290 & $+\mathbf{1 3 . 7 4} \%$ \\
\hline
\end{tabular}

Source: authors' calculations, 2020

Degrees of operating, financial and combined leverage for enterprise $X$ : practical example 2

\begin{tabular}{|l|l|}
\hline \multicolumn{1}{|c|}{ Leverage degrees } & \multicolumn{1}{c|}{ Calculation result } \\
\hline 1 & \multicolumn{1}{c|}{2} \\
\hline Degree of operating leverage & $34.48 \% / 40 \%=0.86$ \\
\hline Degree of financial leverage & $13.74 \% / 34,48 \%=0.40$ \\
\hline Degree of combined leverage & $13.74 \% / 40 \%=0.34$ \\
\hline
\end{tabular}

Source: authors' calculations, 2020

As shown in Table 5, positive percentage changes used in calculating leverage degrees and the leverage degrees below 1 allow concluding that the financial performance of the enterprise 
decreases, irrespective of the fact that the financial performance of the enterprise is still positive (profit is made). In this situation, an increase in net turnover does not generate the same increase in EBIT and net profit for the enterprise (because a higher increase in net turnover results in a lower increase in EBIT and net profit). Overall, if the degrees of financial leverage for the enterprise are below 1 in a long term, this could gradually lead to a decrease in its profit margin. The example shows that at a lower increase in net turnover (40\%), the enterprise has a lower increase in EBIT $(34.48 \%)$ and a much lower increase in net profit (13.74\%).

Situation 3. In calculating a leverage effect, a positive leverage degree occurs if the percentage changes in both the numerator and the denominator of an indicator are negative or if a leverage degree is above 1.

Practical example 3 . The information and calculation results regarding the example are presented in Tables 6 and 7.

Table 6

Changes in the financial performance of enterprise X: practical example 3

\begin{tabular}{|l|c|c|c|c|}
\hline $\begin{array}{c}\text { Financial performance } \\
\text { indicator }\end{array}$ & $\begin{array}{c}\mathbf{2 0 1 8} \\
\text { (EUR) }\end{array}$ & $\begin{array}{c}\mathbf{2 0 1 9} \\
\text { (EUR) }\end{array}$ & $\begin{array}{c}\text { Absolute change } \\
(+;-)(E U R)\end{array}$ & $\begin{array}{c}\text { Relative change } \\
(\mathbf{2 0 1 9 / 2 0 1 8 )} \text { (\%) }\end{array}$ \\
\hline 1 & 2 & 3 & $4=3-2$ & $5=4 \times 100 / 2$ \\
\hline Net turnover & $\mathbf{1 0 0 0 0}$ & $\mathbf{9 0 0 0}$ & -1000 & $-\mathbf{1 0} \%$ \\
\hline $\begin{array}{l}\text { EBIT (profit before interest } \\
\text { and taxes) }\end{array}$ & $\mathbf{2 9 0 0}$ & $\mathbf{1 9 0 0}$ & -1000 & $-\mathbf{3 4 . 4 8 \%}$ \\
\hline Net profit & $\mathbf{2 ~ 1 1 0}$ & $\mathbf{1 1 1 0}$ & -1000 & $-\mathbf{4 7 . 3 9 \%}$ \\
\hline
\end{tabular}

\section{Degrees of operating, financial and combined leverage for enterprise $\mathbf{X}$ :} practical example 3

\begin{tabular}{|l|c|}
\hline \multicolumn{1}{|c|}{ Leverage degrees } & Calculation result \\
\hline 1 & 2 \\
\hline Degree of operating leverage & $-34.48 \% /-10 \%=3.45$ \\
\hline Degree of financial leverage & $-47.39 \% /-34.48 \%=1.37$ \\
\hline Degree of combined leverage & $-47.39 \% /-10 \%=4.74$ \\
\hline
\end{tabular}

Source: authors' calculations, 2020

As shown in Table 7, negative percentage changes used in calculating leverage degrees yield positive leverage degrees, i.e. above 1. In this example, the net profit, EBIT as well as net turnover of the enterprise decrease irrespective of the fact that the leverage degrees are above 1 . How to explain it? The example allows concluding that not only the output but also the financial performance of the enterprise decrease because at a $10 \%$ decrease in net turnover, EBIT decreases by $34.48 \%$ and net profit by $47.39 \%$. This situation has to be viewed negatively.

Situation 4. In calculating a leverage effect, a positive leverage degree occurs if the percentage changes in both the numerator and the denominator of an indicator are negative or if a leverage degree is below 1 .

Practical example 4. The information and calculation results regarding the example are presented in Tables 8 and 9. 
Changes in the financial performance of enterprise X: practical example 4

\begin{tabular}{|l|c|c|c|c|}
\hline $\begin{array}{c}\text { Financial performance } \\
\text { indicator }\end{array}$ & $\begin{array}{c}\mathbf{2 0 1 8} \\
\text { (EUR) }\end{array}$ & $\begin{array}{c}\mathbf{2 0 1 9} \\
\text { (EUR) }\end{array}$ & $\begin{array}{c}\text { Absolute change } \\
(+;-)(E U R)\end{array}$ & $\begin{array}{c}\text { Relative change } \\
(\mathbf{2 0 1 9 / 2 0 1 8}),(\%)\end{array}$ \\
\hline 1 & 2 & 3 & $4=3-2$ & $5=4 \times 100 / 2$ \\
\hline Net turnover & $\mathbf{1 0 0 0 0}$ & $\mathbf{9 0 0 0}$ & -1000 & $-\mathbf{1 0} \%$ \\
\hline $\begin{array}{l}\text { EBIT (profit before interest } \\
\text { and taxes) }\end{array}$ & $\mathbf{2 9 0 0}$ & $\mathbf{2 7 0 0}$ & -200 & $-\mathbf{6 . 9 0} \%$ \\
\hline Net profit & $\mathbf{2 1 1 0}$ & $\mathbf{2 0 0 0}$ & -110 & $\mathbf{- 5 . 2 1 \%}$ \\
\hline
\end{tabular}

\section{Degrees of operating, financial and combined leverage for enterprise $X$ :} practical example 4

\begin{tabular}{|l|c|}
\hline \multicolumn{1}{|c|}{ Leverage degrees } & \multicolumn{1}{c|}{ Calculation result } \\
\hline 1 & 2 \\
\hline Degree of operating leverage & $-6.90 \% /-10 \%=0.69$ \\
\hline Degree of financial leverage & $-5.21 \% /-6,90 \%=0.75$ \\
\hline Degree of combined leverage & $-5.21 \% /-10 \%=0.52$ \\
\hline
\end{tabular}

Source: authors' calculations, 2020

As shown in Table 9, negative percentage changes are used in calculating leverage degrees, as the net profit, EBIT as well as net turnover of the enterprise decrease and the leverage degrees are below 1 . What is an assessment of this situation? The example shows that at a $10 \%$ decrease in net turnover, EBIT decreases to a lesser extent, i.e. by $6.9 \%$ and net profit decreases by $5.21 \%$. Sometimes, the enterprise decreases its output (resulting in a decrease in turnover), yet the EBIT and net profit decreases to a lesser extent, which could not be viewed negatively overall.

Situation 5. In calculating a leverage effect, a negative leverage degree occurs if the percentage change in the numerator is positive, whereas the change in the denominator is negative.

Practical example 5. The information and calculation results regarding the example are presented in Tables 10 and 11.

Changes in the financial performance of enterprise $X$ : practical example 5

\begin{tabular}{|c|c|c|c|c|}
\hline $\begin{array}{c}\text { Financial performance } \\
\text { indicator }\end{array}$ & $\begin{array}{l}2018 \\
\text { (EUR) }\end{array}$ & $\begin{array}{l}2019 \\
\text { (EUR) }\end{array}$ & $\begin{array}{l}\text { Absolute change } \\
(+;-) \text { (EUR) }\end{array}$ & $\begin{array}{c}\text { Relative change } \\
(2019 / 2018),(\%)\end{array}$ \\
\hline 1 & 2 & 3 & $4=3-2$ & $5=4 \times 100 / 2$ \\
\hline Net turnover & 10000 & 9000 & -1000 & $-10 \%$ \\
\hline $\begin{array}{l}\boldsymbol{E B I T} \text { (profit before interest } \\
\text { and taxes) }\end{array}$ & --- & --- & --- & --- \\
\hline Net profit & 2110 & 2200 & +90 & $+4.27 \%$ \\
\hline
\end{tabular}

Source: authors' calculations, 2020

Degrees of operating, financial and combined leverage for enterprise $X$ : practical example 5

\begin{tabular}{|c|c|}
\hline Leverage degrees & Calculation result \\
\hline 1 & 2 \\
\hline Degree of operating leverage & --- \\
\hline Degree of financial leverage & $-\cdots-$ \\
\hline Degree of combined leverage & $+4.27 \% /-10 \%=-0.43$ \\
\hline
\end{tabular}

Source: authors' calculations, 2020 
As shown in Table 12, the example represents a calculation result for a degree of combined leverage; the calculation used one negative indicator (decrease in net turnover) and one positive indicator (increase in net profit). The situation could not unambiguously be viewed positively, as it shows the financial performance of the enterprise is good irrespective of the fact that the leverage degree is a negative number. The example allows concluding that at a $10 \%$ decrease in net turnover, the net profit of the enterprise increases by $4.27 \%$. The example indicates that a decrease in the main economic activity of the enterprise (decrease in net turnover) leads to an increase in the net profit.

Situation 6. In calculating a leverage effect, a negative leverage degree occurs if the percentage change in the numerator is negative, whereas the change in the denominator is positive.

Practical example 6. The information and calculation results regarding the example are presented in Tables 12 and 13.

Table 12

Changes in the financial performance of enterprise X: practical example 6

\begin{tabular}{|c|c|c|c|c|}
\hline $\begin{array}{c}\text { Financial performance } \\
\text { indicator }\end{array}$ & $\begin{array}{l}2018 \\
\text { (EUR) } \\
\end{array}$ & $\begin{array}{l}2019 \\
\text { (EUR) } \\
\end{array}$ & $\begin{array}{c}\text { Absolute change } \\
(+;-)(\text { EUR) }\end{array}$ & $\begin{array}{c}\text { Relative change } \\
(2019 / 2018),(\%)\end{array}$ \\
\hline 1 & 2 & 3 & $4=3-2$ & $5=4 \times 100 / 2$ \\
\hline Net turnover & 10000 & 14000 & +4000 & $+40 \%$ \\
\hline $\begin{array}{l}\text { EBIT (profit before interest } \\
\text { and taxes) }\end{array}$ & --- & --- & --- & --- \\
\hline Net profit & 2110 & 2000 & -110 & $-5.21 \%$ \\
\hline
\end{tabular}

Source: authors' calculations, 2020

Table 13

Degrees of operating, financial and combined leverage for enterprise $X$ : practical example 6

\begin{tabular}{|c|c|}
\hline Leverage degrees & Calculation result \\
\hline 1 & 2 \\
\hline Degree of operating leverage & $\begin{array}{ll}--- \\
\end{array}$ \\
\hline Degree of financial leverage & ---- \\
\hline Degree of combined leverage & $-5.21 \% /+40 \%=-0.13$ \\
\hline
\end{tabular}

Source: authors' calculations, 2020

In Table 13, the calculation of a degree of combined leverage used a negative indicator value (percentage change in net profit) and a positive indicator value (percentage change in net turnover). The situation could unambiguously be viewed negatively, as the financial performance of the enterprise is poor - an increase in net turnover by $40 \%$ results in a $5.21 \%$ decrease in net profit. The example shows that an increase in the main economic activity of the enterprise (increase in turnover) leads to a decrease in the net profit.

\section{Conclusions}

1) By meaningfully applying the degrees of financial leverage, it is possible to enhance the financial performance of enterprises, particularly those engaged in seasonal business, which is typical of rural enterprises. Enterprise output and turnover could fluctuate owing to seasonality. Regardless of fluctuations in turnover, financial leverage degrees allow measuring and assessing the financial performance of an enterprise for making business decisions. 
2) The authors of the paper believe that it is important to take into account percentage changes in the indicators used in the calculation of financial leverage degrees, as it is important whether the percentage changes are positive or negative.

3) Positive leverage degrees should be assessed based on percentage changes (positive or negative) in the indicators used in the calculation of financial leverage degrees.

4) The effects of financial leverage degrees on the financial performance of an enterprise at positive degree values - the percentage changes in both the numerator and the denominator of any indicator used in the calculation are positive - should be viewed as follows: the financial leverage degrees and their effects on the financial performance of an enterprise should be viewed positively $(+)$ if a leverage degree is $>1$ and negatively $(-)$ if a leverage degree is $<1$.

$5)$ In contrast, at negative degree values, the effects of financial leverage degrees on the financial performance of an enterprise should be viewed depending on what percentage changes in the numerator and the denominator of any indicator - positive or negative - are used in the calculation. If a percentage change is positive in the numerator and negative in the denominator, the effects of financial leverage degrees on the financial performance of an enterprise should be viewed positively (+). If a percentage change is negative in the numerator and positive in the denominator, the effects of financial leverage degrees on the financial performance of an enterprise should be viewed negatively (-).

\section{References}

1. Amaro de M., J. (2001). Theoretical Foundations of Corporate Finance. Princeton University Press. IBNS 0691-09794-6.

2. Berk, J., DeMarzo P. (2014). Corporate Finance. The Core, Perason Education Limited. ISBN-13:978-0-27379216-1.

3. Brealey, R., A., Myers S., C., Allen, F. (2014). Principle of Corporate Finance. McGraw-Hill Education. ISBN: 139780077151560

4. Brealey, R., A., Myers, S., C., Allen, F. (2016). ISE Principles of Corporate Finance. McGraw-Hill Education.

5. Corelly, A. (2016). Analytical Corporate Finance. Springer International Publishing Switzerland. ISSN: 21924333. ISBN: 978-3-319-39548-7 ISBN (eBook): 978-3-319-39549-4. pp.208.-212.

6. Darrat A., F., Mukherjee, T., K. (1995). Inter-industry Differences and the Impact of Operating and Financial Leverages on Equity Risk. Review of Financial Economics. Volume 4, Issue 2, Spring 1995, pp.141-155.

7. Emery, D., R., Finnerty, J., D. (1997). Corporate Financial Management. Prentice-Hall, Inc. ISBN 0-13433533-3.

8. Gaddefors, J., Korsgaard, S., Bruun, I., M. (2020). Regional Development through Entrepreneurial Exaptation: Epistemological Displacement, Affordances, and Collective Agency in Rural Regions. Journal of Rural Studies. Volume 74, February 2020, pp.244-256.

9. Hart, O. (1995). Firms, Contracts, and Financial Structure. Oxford University Press. ISBN 0-19-828850-6, pp. 126-155.

10. Jean, T. (2006). The Theory of Corporate Finance. Princeton University Press. ISBN - 13: 978-0-691-125562.

11. Jones, C., P. (1992). Introduction to Financial Management. Irwin, Boston, ISBN 0-256-07311-2, pp. 449481.

12. Kedzo M., G., Zrinka, L. (2020). The Financial Efficiency of Small Food and Drink Producers across Selected European Union Countries Using Data Envelopment Analysis. European Journal of Operational Research, Published by Elsevier B.V., 2020.

13. Leibus, I. (2019). Tax incentives for micro enterprises - Latvia's experience. Proceedings of the International scientific conference "Economic science for rural development", Jelgava, 2019. Latvia University of Life Sciences and Technologies. Faculty of Economics and Social Development. No 52 : New Dimensions in the Development of Society. Home Economics. Finance and Taxes. Bioeconomy, p. 287-295. - ISBN 9789984483221 - ISSN 2255-9930

14. Li, Z., Li, Q., Zeng, Y. (2020). Contraction Flexibility, Operating Leverage, and Financial Leverage. Journal of Management Science and Engineering, Available online 18 February 2020, ScienceDirect, 2020.

15. Moles, P., Parrino, R., Kidwell, D. (2011). Corporate Finance. John Wiley \& Sons Ltd. ISBN 978-0-470-683705.

16. Moyer, C., R., Mcguigan J., R., Kretlow, W., J. (1998). Contemporary Financial Management. International Thomson Publishing. ISBN - 0-538-87776-6., pp. 459-482. 
17. Perez-Gomez, P., Arbelo-Perez, M., Arbelo, A. (2018). Profit Efficiency and its Determinants in Small and Medium-sized Enterprises in Spain. BRQ Business Research Quarterly Volume 21, Issue 4, October-December 2018. ScienceDirect, 2018, pp. 238-250.

18. Stelk, S., Park, S.-H, Medcalfe, S., Dugan, M., T. (2017). An Additional Analysis of Estimation Techniques for the Degree of Financial Leverage. ScienceDirect, 2017.

19. Sarkar, S. (2018). Optimal DOL (degree of operating leverage) with Investment and Production Flexibility. ScienceDirect, 2018. International Journal of Production Economics, 2018.

20. The National Development Plan 2021-2027.

21. Yang, R., Xia, K., Wen, H. (2016). Venture Capital, Financial Leverage and Enterprise. Procedia Computer Science 91, 2016, ScienceDirect, 2016, pp.114.-121. 